\title{
Effect of different meteorological parameters on the development and progression of rice leaf blast disease in western Odisha
}

\author{
RINI PAL*, DIPANKAR MANDAL AND BHIMA SEN NAIK
}

All India Coordinated Rice Improvement Project, Regional Research and Technology Transfer Station, O.U.A.T., Chiplima, SAMBALPUR (ODISHA) INDIA (Email: bsnaikouat@ rediffmail.com; dipankarpatho@ gmail.com)

\section{ARITCLE INFO \\ Received : 19.12 .2016 \\ Revised : 28.02 .2017 \\ Accepted : 05.03.2017}

\section{KEY WORDS :}

Rice, Leaf blast, Weather parameters

*Corresponding author:

Email : rinipatho@gmail.com

\begin{abstract}
Blast disease is one of the most destructive diseases of rice. Epidemiological factors affect greatly on the disease establishment, development and severity resulting in huge crop losses. A field experiment was conducted at All India Co-ordinated Rice Improvement Project, Regional Research and Technology Transfer Station, Chiplima, Sambalpur, Odisha to find out the effect of weather parameters on severity of leaf blast disease during the growing season 2013-14 and 2014-15. The result revealed that both relative humidity and rainfall were positively correlated with leaf blast severity. On the contrary, the temperature and disease severity was found to be negatively correlated which indicated that the disease increased with the decrease of temperature. A maximum relative humidity of 90-95 per cent and total rainfall of more than $280 \mathrm{~mm}$ accompanied by $28^{\circ} \mathrm{C}$ temperature were found favourable for disease development and spread. However, still more epidemiological studies are required to strengthen the forecasting and prediction mechanism of the disease which will ultimately minimize the yield losses caused by the disease.
\end{abstract}

How to view point the article : Pal, Rini, Mandal, Dipankar and Naik, Bhima Sen (2017). Effect of different meteorological parameters on the development and progression of rice leaf blast disease in western Odisha. Internat. J. Plant Protec., 10(1) : 52-57, DOI : 10.15740/HAS/IJPP/ 10.1/52-57. 